\title{
Analysis of Trade in Goods between Indonesia and South Korea on Cooperation Forum IKCEPA
}

\author{
Ragimun Abdullah \\ Ministry of Finance, Republic of Indonesia \\ ragimun@gmail.com
}

\begin{abstract}
Indonesia Korea Comprehensive Economic Cooperation Partnership (IKCEPA) arises from the desire of both countries to boost trade performance and make the free trade agreement more comprehensive. CEPA agreement with South Korea has targeted the reduction and elimination of tariffs that cover more products and services. This study analyzed the relationship between Indonesia merchandise trade cooperation with South Korea. Besides, look at the potential of the Korean market for goods exports from Indonesia featured. To deepen the study simple equilibrium analysis is used to analyze the potential of the South Korean market for goods exports Indonesia. The analysis showed that after the implementation of AKFTA in 2007, Indonesia merchandise trade performance by sector turned out to have an average growth of imports by 21.36 percent, higher than the average export growth of 8.19 percent. There are some items which have the potential to become a mainstay of exports to Korea that includes textiles, wood processing, manufacturing goods such as spare parts of household appliances, bicycles and others. Likewise, there are some agricultural products such as pineapple, guava, and animals such as freshwater fish, crabs, cuttlefish and others. However, the export of these items to South Korea is still hampered by their tariff barriers. Forum IKCEPA cooperation can be a bridge to fill the gap between the two countries for tariff reduction, market acces and an increase in exports of both countries.
\end{abstract}

Keywords: IKCEPA, negotiation, export

\section{Introduction}

Open economy is an economy that involves international trade (exports and imports) in goods and services and capital with other countries. The era of free trade is currently growing with the number of bilateral agreements, regional and multilateral. Disclosure can not be separated from the high dependence on import tariffs as a source of government revenue that would impede the process of trade openness in the economy. But slowly began to diminish with the existence of free trade agreements among trading partner countries. Tariffs and other non-tariff barriers is the main policy instrument that was originally used to protect the industry which is the domestic import substitution. With the liberalization of trade, the economy is expected to further improve. Relations with the national economy through international trade is now unavoidable. It shows a strong relationship to economic conditions in trading partner countries. Their relevance between economic openness with domestic prices, which causes the price of domestic goods would be affected the structure of trading partner economies. Many things that drive a country to international trade adheres to an open economy, such as differences in available resources to expand the market share of national production with a relationship of international trade policy and many other things that affect (Boediono, 1981).

Cooperation Indonesia Korea Comprehensive Economic Partnership Agreement (IKCEPA) is one of the cooperative relationship that arises from the desire of both countries to increase trade and investment performance. Indonesia-Korea CEPA aims to make a free trade agreement that is more comprehensive than the ASEAN Free Trade Agreement with South Korea (AKFTA) beforehand. In the CEPA agreement with South Korea have targeted the reduction and elimination of tariffs that cover more products, liberalization of the services sector is more ambitious, as well as elements of a more solid investment protection. Indonesia and Korea agree that the cooperation forum IKCEPA formed based on three main pillars, namely market access of trade in goods and services, trade facilitation and investment, as well as cooperation and capacity building. In the future, the challenges faced in this IKCEPA cooperation is their market access to Indonesia in South Korea is still open, improvements in the quality and diversification of products. It is expected also to an increase in economic partnership is strategic, comprehensive and innovative. Besides, in the negotiation of this cooperation will get the same understanding related to quarantine regulations, packaging and delivery time for both countries. Short-term targets are the IKCEPA cooperation facilitates the achievement of trade between the two countries amounted to US $\$ 100$ billion by the year 2020, while the long term targets is the continuity of trade economic cooperation to stimulate the economy of both countries. For Indonesia, this 
cooperation is expected to expand market access in South Korea. In addition, as an effort to increase the promotion of Indonesian products to Korea. While Korea advantage with this agreement is the fulfillment of a number of commodities that are needed in the country of Indonesia to support its economy.

\section{Literature Review}

Indonesia as a country that adheres to an open economy, then to push the national economy but to rely on the domestic economy is also developing various forms of international cooperation multilateral, regional and bilateral. Indonesia Korea Comprehensive Economic Partnership Agreement (IKCEPA) is one of the bilateral economic agreements between Indonesia and South Korea. IKCEPA also a strategic step for both countries to improve economic relations, trade and investment. It is hoped that this cooperation can be achieved benefit for both parties in order to improve the welfare of the people of both countries through trade activities. Foreign trade allows a country to learn more efficient of production techniques and ways for more modern management including the transfer of technology, that is often referred to as the commercialization of the technology. It is intended as the process of transfer of skills, knowledge, technology, manufacturing method, a sample of the manufacturing and government facilities, universities and other institutions that guarantee the development of science and technology can be accessed by multiple users. It becomes important for the further development and use becomes a process, application, materials and products as well as products of other new services. Transfer of technology is divided into two, namely the transfer of both horizontally and vertically transfer. Horizontally is the transfer of technology from one field to another. While the vertical transfer is the transfer of technology from research to implementation (Grosse, 1996).

To realize this IKCEPA cooperation, a study group has been assessing the feasibility of CEPA that startedduring the visit of Coordinating Minister for Economic Affairs of the Republic of Indonesia to Seoul in February 2011. After some time the study group doing the assessment, then endorsed the final report on the first meeting of Working level Task Force Meeting (WLTFM) in Seoul in October 2011. Several seminars have also been implemented in each country to disseminate study results to the national stakeholders. The study of the Joint Study Group for a Comprehensive Economic Partnership Agreement Between Indonesia and Korea (JSC IKCEPA) concluded that further liberalization of the tariff on the product categories Sensitive Track (ST) are not ready for liberalization. This Sensitive Track consists of two products, namely the Sensitive List (SL) and Highly Sensitive List (HSL). This provision according to the agreement Asean Korea Free Trade Agreement (AKFTA) which will increase prosperity for both countries is estimated to be worth US \$ 7.97 million or 0.03 percent increase in GDP for Indonesia and \$ 1.5 billion, equivalent to an increase in GDP of Korea South by 0.13 percent. With the existence of this bilateral cooperation, Indonesia will gain enormous benefits through economic cooperation, which amounted to USD 10.6 billion, which is equivalent to a 4.37 percent increase in GDP of Indonesia. This benefit is an increase of $\pm 1: 36$ times of the benefits derived from trade in goods which only amounted to USD 7.79 million (De Silva, 2012).

However, the report did not report on the benefits South Korea through the economic cooperation. For the record, within the framework of AKFTA, about 90 percent of tariffs Indonesia and 92.1 percent of South Korea's tariffs included in the category of Normal Track (NT), which currently has import duty rates of 0 percent, and the rest is a product in a category Sensitive Track (ST), which consists of a Sensitive List (SL) and Highly Sensitive List (HSL). In March 2012, the two leaders held bilateral talks and agreed to start negotiations on IKCEPA. The talks first held on July 12, 2012 in Jakarta, discusses the Term of Reference (TOR) negotiations of IKCEPA also the scope IKCEPA, namely: Trade in Goods, Rules of Origin, Customs, Trade Facilitation, Investment, Intellectual Property Rights, Sustainable Development and Competition. (WTO, 2012). Currently IKCEPA is at the final stage of negotiations. Points to be a major obstacle in the negotiation of Indonesia-Korea CEPA are: (i) Indonesia wants investment commitments from Korea to be included in legal documents CEPA, while for Korea is very difficult to fulfill that; (Ii) Indonesia still could not accept the proposal of Korea related reduction in tariffs for sensitive products and compete directly with Korea, such as Iron and Steel; and (iii) Indonesia is still considering to liberalize the telecommunications sector according Korean proposal (PKRB, 2013).

In essence FTA is a commitment for members of treaty signatories to reduce or eliminate tariffs on imported goods originating FTA partner countries while maintaining import tariffs Most Favoured Nation (MFN) from 
countries outside the FTA partners. In fact, every member of FTA maintains its tariff regime. This will bring three things, namely (i) the FTA should be based on the rules of origin (ROO), the absence of ROO will lead to abuse facility for non member countriesof the FTA with the conduct transhipment in member states FTA with low rates and then goods horse re-exported to countries members of the FTA, (ii) expected to occur varying prices in the member states of the FTA because member states will choose varying rates, (iii) although they still maintain tariff regime of its (MFN) for countries not members of the FTA, but such autonomy can make any particular government more susceptible to a particular group at the national level. Basically a preferential trade agreement (preferential trade agreement) such as the Free Trade Agreement (FTA) has positive and negative sides. And to provide alternatives to policy in the field of trade, we can observe in the following Viner's model (TMUG, 2014).

Graph 1: Viner's Model

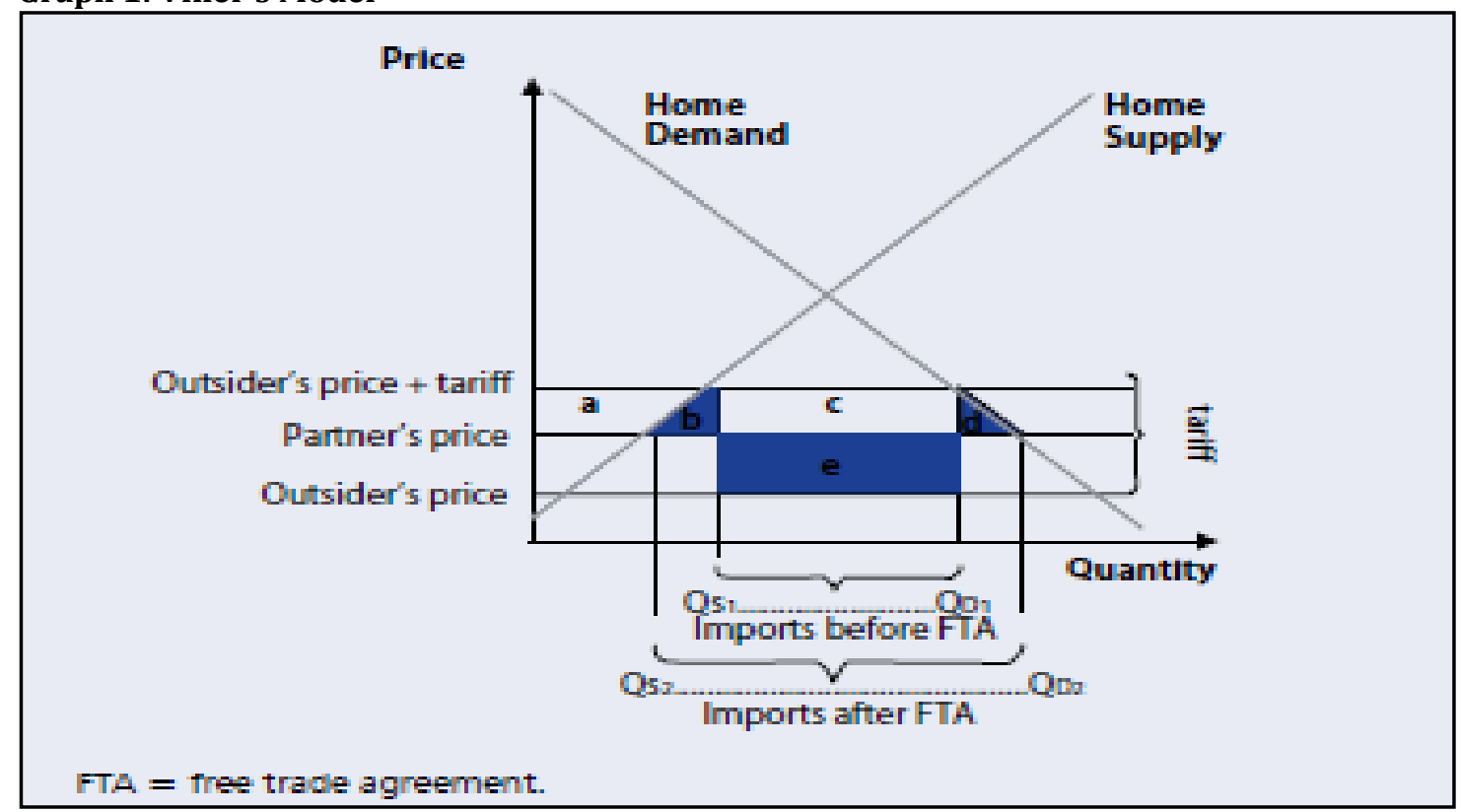

(Source) Methodology for Impact Assessment of Free Trade Agreement, OECD

Viner (1950) concluded that to measure the impact of trade liberalization on a cooperation agreement between countries to compare the effects of positive and negative effects of liberalization: First, the positive effects: trade creation, where a shift of consumption of domestic products that are high-cost to imported products that are low-cost (produced by partner countries). Second, negative effects: trade diversion, ie intermediate consumption of imported products that are low-cost (which is produced by non-members) to the import of products that are highcost (generated by the cooperation partner countries in the FTA).

\section{Methodology}

This study aimed to analyze the relationship of cooperation trade in goods and the market potential of South Korea for the main export goods from Indonesia. To deepen the study, simple equilibrium analysis is used to analyze the potential of the South Korean market for goods exports Indonesia. Indicative Potential Trade is also used as an approach. Indicative Potential Trade is a methodology introduced by Christian Helmers and Jean Michel Pasteels (ITC Working Paper, 2006), which can make an assessment of the export potential based on the level of its products. This methodology uses an approach that combines macro and micro indicators. The initial step of this methodology is to establish a certain level of disaggregation trade.

This methodology is illustrated using examples of real world trade, which was originally used in a study conducted by the German Development Cooperation CTZ investigating the potential of bilateral trade in some commodities between Mongolia with partner countries. Simply put products imported into a country or destination is an indication of the existing demand (existing demand), and products dieksor by a country to 
the world is an indication of the existing offer (existing supply). Indicative Trade Potential (ITP) can be calculated by, first, forming wedges of performance Demand, supply, and existing trade transactions. Second, calculate ITP is based on the equation below:

Where:

$$
\begin{aligned}
& \text { ITP }=X_{i w}-X_{i k}, \text { If } I_{k w}>X_{i w} \\
& \text { ITP }=I_{k w}-X_{i k}, \text { If } I_{k w}<X_{i w}
\end{aligned}
$$

$X_{i w}$ is Indonesia's exports to the world (supply)

$X_{i k}$ is Indonesia's exports to Korea (existing)

$I_{k w}$ is Korean imports to the world (demand)

Generally to analyze IPT results can be explained as follows:

- See the difference (gap) between the proportion of Indicative Potential Trade (IPT) with Ratio (Existing / Demand), so that this difference can be seen from the performance of Indonesia's trade with South Korea and viewable potential export goods go to South Korea. For example, for the goods "Cedar" HS 440710100 numbers obtained ratio of 0 per cent and 0.14 per cent of the value of IPT, the next should be seen Indonesia's export performance.

- When looking Indonesia in the world trade performance. For goods "Cedar" Indonesia has been supplying to the world amounted to USD 701000 excluding South Korea country.

- World trade performance for the goods to South Korea "Cedar" amounted to USD 513.574 million, meaning that demand for goods Cedar in South Korea is quite large.

- Meanwhile, Indonesia's trade performance of South Korea showed that the value of the goods "Cedar" turned out to 0 . This means that there is potential for these goods can be negotiated to the South Korean government. Furthermore, to be seen how tariffs applied in AKFTA forum and how rates MFNnya Korea.

- AKFTA rates (rates Asean agreement South Korea), it turns out fare "Cedar" is still 5 per cent, in other words, there are still tariff barriers in order to go to South Korea to ASEAN countries, including Indonesia.

- South Korea MFN rates, it turns out one obstacle is fare "Cedar" to South Korea. These countries still impose tariffs of 5 percent. This is what must be explored and as a reference to be negotiated with the South Korean government.

Data: The data used is secondary data import export South Korea and Indonesia as well as the world, while the source data comes from Statistics Indonesia, UN Comtrade, the Organisation for Economic Cooperation and Development (OECD) as well as data from the International Trade Centre (ITC).

\section{Results and Discussion}

Indonesia Import Export Performance: For more than a decade from 2004 through 2014, the performance of export-import of Indonesia has been ups and downs. Indonesian imports increased and peaked in 2012, and after that it fell back. Indonesia's main import partner countries has been changing time to time. In 2004, Indonesia main import partners are Singapore, Japan, China, the United States (US), Australia and South Korea. However, the data in 2014, Indonesia's main import partners are China, Singapore, Japan, South Korea, Malaysia and the United States. Imports from Indonesia, has tripled portion of the middle class population, boosting from the demand for fuel oil and consumer goods that becomes higher. Indonesia's major imports are oil and gas (about 24 percent of total imports), machinery (19 per cent), electrical appliances (13 percent), iron and steel ( 7 percent), vehicles ( 6 percent) and plastics ( 5.5 percent). Over the last ten years the development of Indonesian imports, as shown by the graph below. 


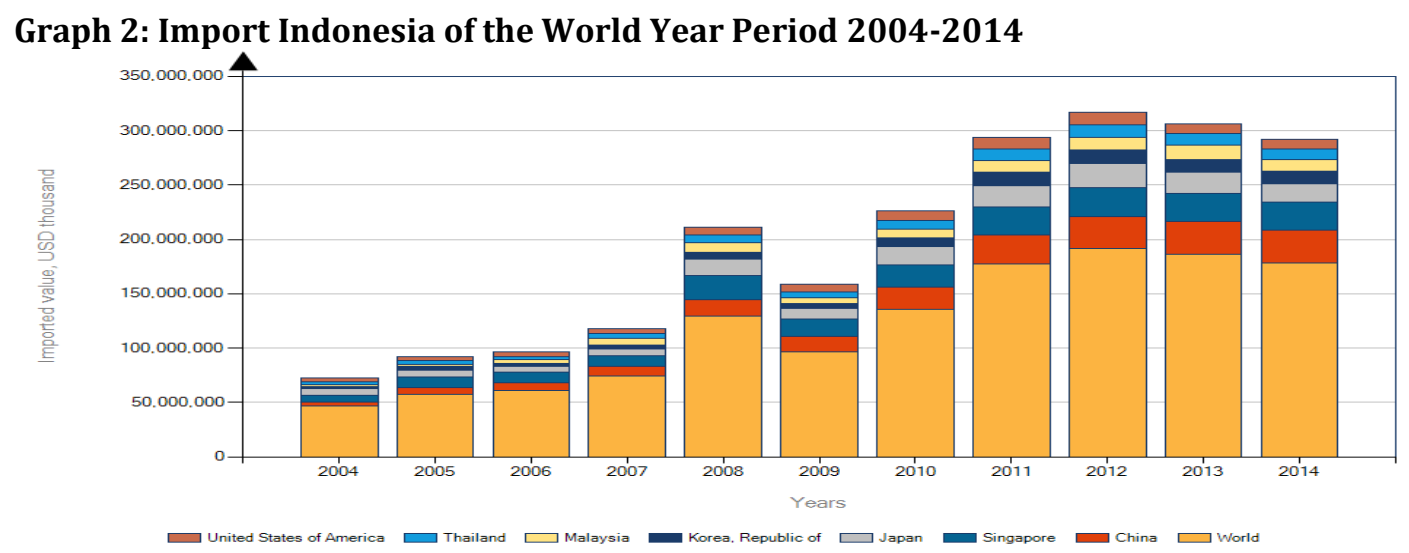

(Source) ITC, 2014

One mainstay of Indonesia's economic growth is the contribution of the growth of exports from Indonesia to the world. Export is heavily influenced by internal factors such as increasing competitiveness and external factors such as global economic conditions. Some of the main Indonesian export products include oil and gas (18 percent of total exports), mineral fuels and oils (14 percent), animal and vegetable fats and oils (11 percent), electrical equipment and machinery (6 percent). Other exports include: rubber and rubber processing, ores, slag and ash, nuclear reactors and boilers and vehicles (Juan, 2014). During the 10 years of Indonesian exports can be seen in Figure 3 as follows:

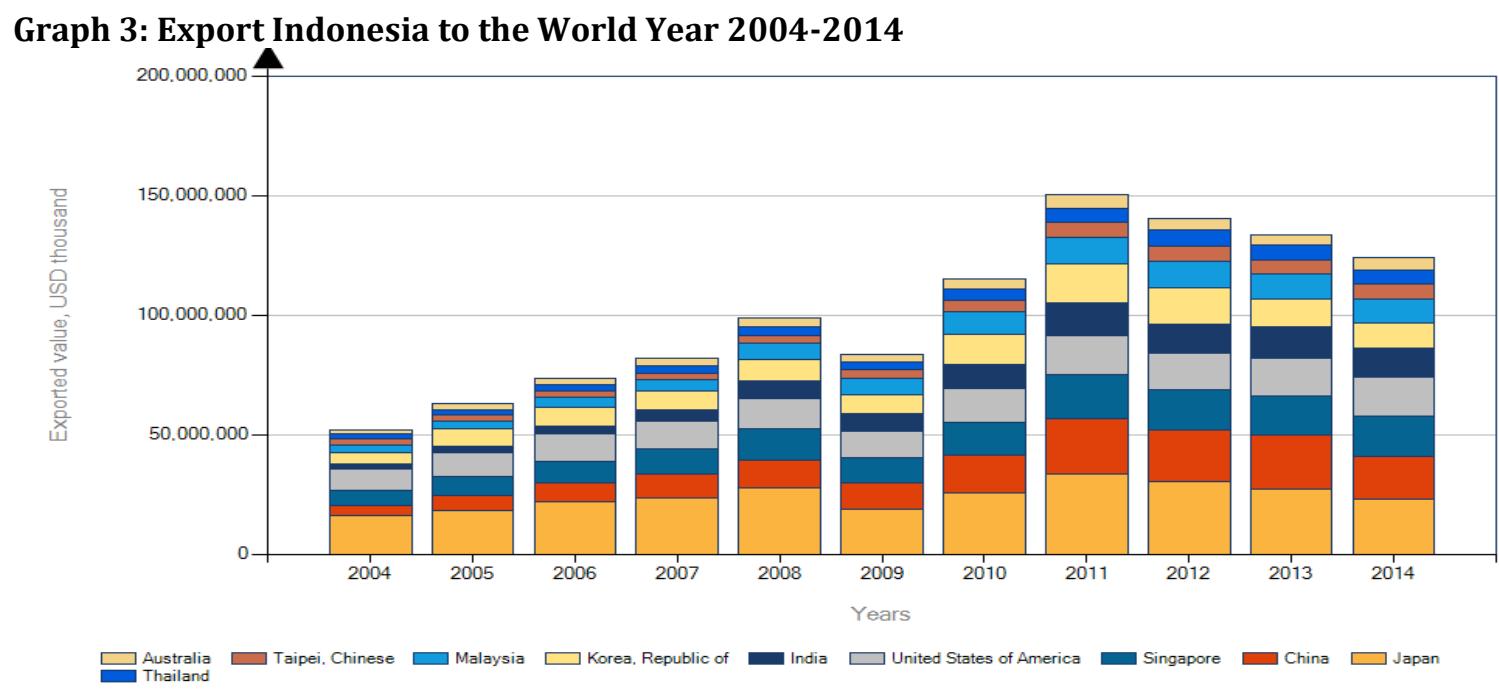

(Source) ITC, 2014

Indonesia's export to main destination countries in 2014 amounted to $\$ 23,127,089$, namely Japan, followed by China amounted to $\$ 17,605,944$, Singapore amounted to $\$ 16,752,340$, and South Korea amounted to $\$$ $10,606,000$. Although the general trend of the ten-year average Indonesian exports have increased, but in fact there has been a trend in the last five years of stagnation and even a declining trend in the past year, as pictured on the graph 3 above.

Developments Trade Relations Indonesia South Korea: In particular, when viewed from the flow of trade between Indonesia and South Korea,the trend for has been turning up and down for both exports and imports between the two countries. However, in 2014 Indonesia experienced a trade deficit. 


\section{Graph 4: Trend Trading Indonesia-Korea 2000-2014}

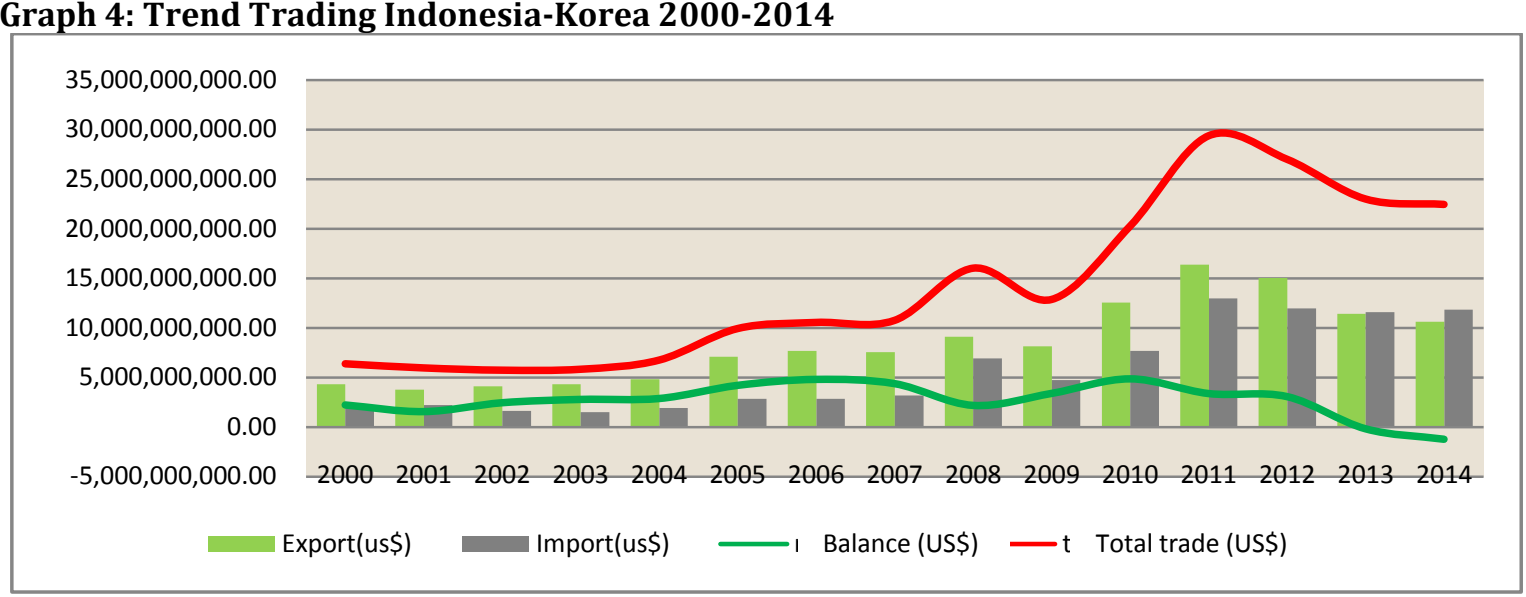

(Source) UN Comtrade, processed

In almost all the period, Indonesian exports dominate the trade balance with South Korea, but the last two years the value of imports from South Korea continue to increase and become involved in the trade balance deficit. The proportion of export products from Indonesia to South Korea market is not yet significant, which is ranked at 12th position in 2014, which amounted to USD 12,271,095,000. During this time the main partner for South Korea is China with imports amounted to USD 90,072,159,000, and then Japan amounted to USD 53,775,979,000, United States amounting to USD 45,532,370,000, and Saudi Arabia amounted to USD $36,724,136,000$. Indonesia is ASEAN countries which have the highest proportion in South Korean imports, followed by Singapore and Malaysia, which amounted to USD 11,306,787,000 and \$11,100,597,000. As seen in Figure 5.

\section{Graph 5: South Korean imports of the world}

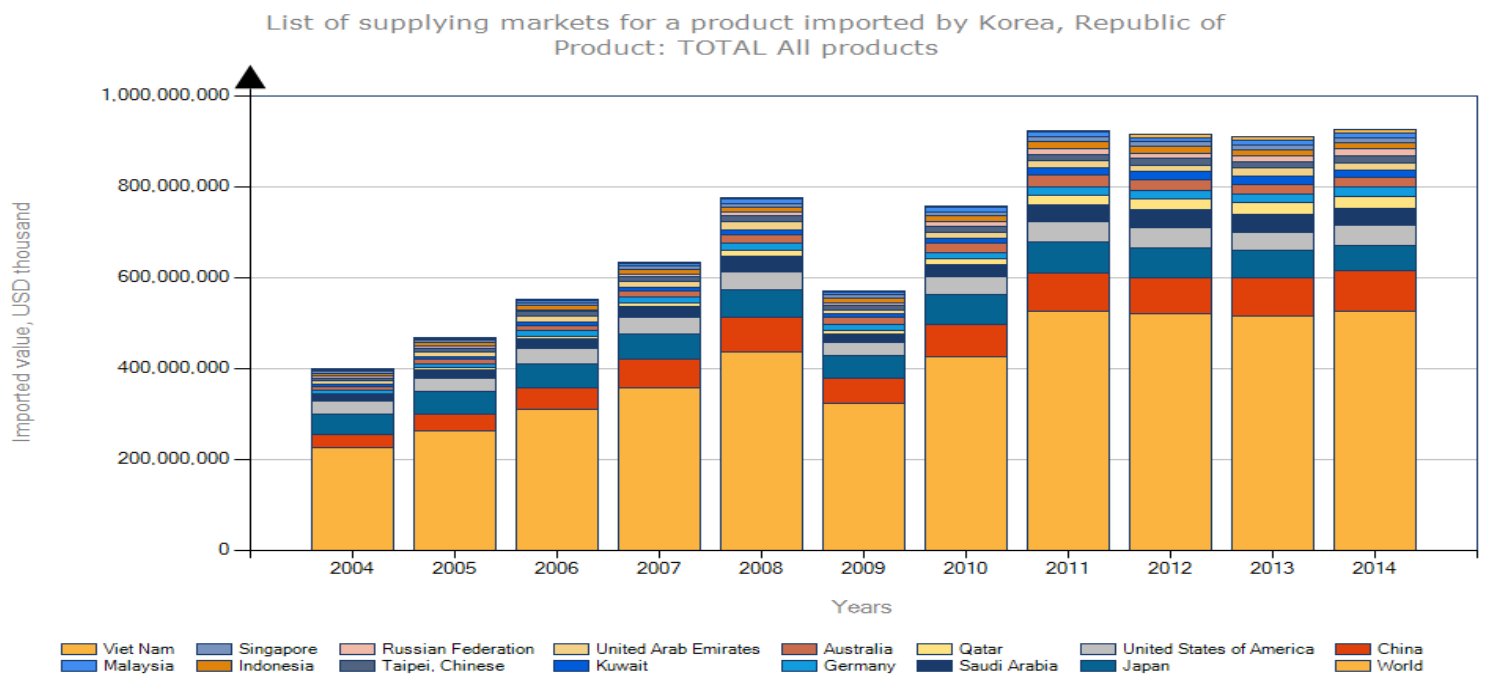

(Source) ITC, 2015

South Korea's main import products in 2014 are products that are used to support the industry, such as petroleum oil (18.07 percent), liquefied natural gas (5.84 percent), light petroleum oil (4.17 percent), processors (3.12 percent), bituminous coal (2.04 percent), iron ores (1.51 percent), electronic integrated circuit (1.42 percent), as well as parts of telephone (1.12 percent). As Table 1 below. 
Table 1: Main Import Products South Korea Year of 2014

\begin{tabular}{|c|c|c|c|c|}
\hline NO. & HS Code & Product Label & $\begin{array}{l}\text { Imported Value } \\
\text { (USD) }\end{array}$ & $\%$ \\
\hline 1 & '270900 & $\begin{array}{l}\text { Petroleum oils and oils obtained from } \\
\text { bituminous minerals, crude }\end{array}$ & $94.971 .596,00$ & 18,07 \\
\hline 2 & '271111 & Natural gas, liquefied & $31.423 .901,00$ & 5,98 \\
\hline 3 & '271012 & Light petroleum oils and preparations & 21.897.149,00 & 4,17 \\
\hline 4 & '854231 & $\begin{array}{l}\text { Electronic integrated circuits as processors } \\
\text { and controllers, whether }\end{array}$ & $16.416 .096,00$ & 3,12 \\
\hline 5 & '270112 & $\begin{array}{l}\text { Bituminous coal, whether or not pulverised } \\
\text { but not agglomerated }\end{array}$ & $10.723 .078,00$ & 2,04 \\
\hline 6 & '260111 & $\begin{array}{l}\text { Iron ores\&concentrates,oth than roasted iron } \\
\text { pyrites,non-agglomerated }\end{array}$ & $7.959 .540,00$ & 1,51 \\
\hline 7 & '271019 & Other petroleum oils and preparations & $7.760 .657,00$ & 1,48 \\
\hline 8 & '854239 & $\begin{array}{l}\text { Electronic integrated circuits (excl. such as } \\
\text { processors, controllers, }\end{array}$ & $7.439 .705,00$ & 1,42 \\
\hline 9 & '854232 & Electronic integrated circuits as memories & $5.908 .469,00$ & 1,12 \\
\hline 10 & '851770 & $\begin{array}{l}\text { Parts of telephone sets, telephones for } \\
\text { cellular networks or for other }\end{array}$ & $5.860 .128,00$ & 1,12 \\
\hline 11 & '848620 & $\begin{array}{l}\text { Machines and apparatus for the manufacture } \\
\text { of semiconductor devices or }\end{array}$ & $5.197 .125,00$ & 0,99 \\
\hline 12 & '260300 & Copper ores and concentrates & $3.635 .810,00$ & 0,69 \\
\hline 13 & '870332 & $\begin{array}{l}\text { Automobiles with diesel engine displacing } \\
\text { more than } 1500 \mathrm{cc} \text { to } 2500 \mathrm{cc}\end{array}$ & $3.056 .597,00$ & 0,58 \\
\hline 14 & '854140 & $\begin{array}{l}\text { Photosensitive semiconduct } \\
\text { device,photovoltaic cells\&light emit diodes }\end{array}$ & $2.891 .787,00$ & 0,55 \\
\hline 15 & '720449 & Ferrous waste and scrap, iron or steel, nes & $2.828 .226,00$ & 0,54 \\
\hline 16 & '847989 & $\begin{array}{l}\text { Machines \& mechanical appliances nes } \\
\text { having individual functions }\end{array}$ & $2.784 .714,00$ & 0,53 \\
\hline 17 & '100590 & Maize (corn) nes & $2.629 .308,00$ & 0,50 \\
\hline 18 & '271113 & Butanes, liquefied & $2.592 .471,00$ & 0,49 \\
\hline 19 & '901380 & $\begin{array}{l}\text { Optical devices, appliances and instruments, } \\
\text { nes, of this Chapter }\end{array}$ & $2.585 .091,00$ & 0,49 \\
\hline 20 & '853400 & Printed circuits & $2.583 .840,00$ & 0,49 \\
\hline
\end{tabular}

(Source) ITC, processed

In 2004-2008, there was no major change in trade policy formulation in South Korea. Regulatory reform continue to be made in South Korea with an emphasis on reducing the number of quantitative regulatory policies in order to improve the quality of regulation. After that, South Korea trade policy has also not changed much. Things that encourage trade and investment policies of South Korea is in order to achieve greater liberalization. This is done by increasing productivity and deployment of resource allocation more efficiently. However some protectionist measures to protect domestic producers continue in South Korea, especially farmers, from foreign competition is maintained (TPR, 2004)

Discussion: To see a potential indicator of trade especially export potential of Indonesia to South Korea based on the level of product in IKACEPA forum, can be described in Matrix Calculation Indicative Potential Trade between Indonesia and South Korea. From the analysis of the market potential of Indonesia's exports to South Korea can be used as a basis for policy making the Government of Indonesia to negotiate rates trade in goods with South Korean government. Here are the results of analysis using approach of Indicative Potential Trade. The data used is data of 2014 as many as 12232 items of goods HS Indonesia's main export. 
Of these, taken $30 \mathrm{HS}$ items that potentially could be negotiated with the South Korean government that can be summarized as follows (Appendix 1):

- 6-digit HS 040221, in the form of milk powder Whole milk powder HS 0402211000. This has the proportion of IPT 100 percent. Export or supply of merchandise from Indonesia to the world is very big which is USD 36.681 million while the South Korean demand for USD 10.145 million and Indonesia's exports to South Korea amounted to zero. When looking at constraints which include tariffs remain high at 17 percent good or MFN tariff rates AKFTA South Korea.

- 6-digit HS 252310, goods Cement Clinkers 2523100000. Merchandise HS also has the potential can go to South Korea. IPT its proportion of 100 percent. Cement exports from Indonesia to the world worth USD 12.597 million while South Korea demand of the world worth USD 1.449 million while the supply from Indonesia yet so these items can be negotiated with South Korea. Tariff barriers to AKFTA by 5 percent and tariffs on entry to South Korea or South Korea MFN also by 5 percent.

- 6-digit HS 010620, in the form of goods Fresh Water Tortoises HS 010620200. This item is in the form of a turtle or turtle lives in freshwater. South Korea is quite highly demand, and supply Indonesia to the world is also quite high. However, supply to Korea from Indonesia only 10 percent of South Korea's needs. Barriers to entry to South Korea turned out to be the rate charged 8 percent. Likewise AKFTA forum also still apply the rate of 8 percent.

- 6-digit HS 310221, in the form Of Red Ginseng HS 3301904520. This item has ITP proportion of 100 percent. Indonesia supplies to the world market worth USD 88.535 million while world supplies to South Korea worth USD 21.45 million. However, Indonesia's exports to South Korea are still zero. When viewed barrier AKFTA rate was 7 percent and 7 percent of South Korea MFN rates.

- 6-digit HS 291611, in the form of Acrylic acid chemistry Goods 2916111000. HS also has a great opportunity to enter the South Korean market. From the IPT simulation results, turns out that this chemical stuff has value IPT proportion of 100 percent. South Korea demand of USD 49.065 million supplied from the world, while supply from Indonesia for USD 31,000 while Indonesia could supply the world worth USD 55.2267.000. To rate this chemical goods in AKFTA was still by 7 percent and in South Korea MFN rates are also still at 7 percent.

- 6-digit HS 210310, Soy Sauce or Soya Sauce HS 2103100000. Goods processed form of soy has the potential to be able to sign South Korean market because it has a 98.29 percent proportion IPT. Indonesia to the world supply of USD 14.202 million and South Korea demand in 2014 of USD 6.768 million while the supply Indonesia to South Korea only worth $\$ 116,000$. It means that the goods in form of soya sauce still have the opportunity to go to South Korea. However, barriers still AKFTA rates by 8 percent and South Korea MFN tariff of 8 percent as well.

- 6-digit HS 441299, such as Whole Of a thickness not less than $6 \mathrm{~mm}$ HS 4412991011. processed wood products has a great potential entry into South Korea with a proportion of 98.08 percent IPT. These goods are exported to the world worth USD 713.983 million and South Korea supplied from the world worth USD 85.273 million, but the supply Indonesia to South Korea are still slightly only worth \$ 1.633 million. AKFTA tariff barriers for MFN tariffs by 13 and South Korea at 10 percent.

- 6 digit, HS 290516, 2-ethylhexyl alcohol goods with HS Goods 2905161000. This chemical has the potential to enter the South Korean market. A proportion of IPT of these goods has a proportion of total 98.06 percent. Indonesian exports of these goods to the world all have considerable value of USD 174689000 while South Korea imported from the world amounted to USD 166.773 million and imports from Indonesia amounted to only USD 3.229 million. It is still hampered partly because of tariff barriers. For AKFTA rate of 6 percent and South Korea MFN tariff is still at 6 percent.

- 6-digit HS 290711, in the form of chemical goods Phenol 2907111000. HS also has great potential to get into the South Korean market because the IPT proportion of 94.77 percent. Indonesia's exports to the world market of goods worth USD 64.704 million while South Korea to the world's supply higher at USD 68.263 million and Indonesia only supply to South Korea worth USD 9,000 only. When looking at the goods tariff turns AKFTA rate remained at 6 percent and South Korea MFN tariff is still 6 percent.

- 6-digit HS 850610, in the form of Manganese batteries with a HS 850610100. This item has IPT proportion of 95 percent. Indonesia's export products have been supplied to the worldwide market valued at USD 178.414 million while the world supplying to South Korea worth USD 57.378.00. The 
new Indonesian exporting to South Korea worth USD 2.868 million. Hamabatan rate this product for AKFTA and South Korea MFN tariff of 13 percent.

- 6-digit HS 390210, in the form of plastic ore Polypropylene (PP) with HS 3902100000. This PP has IPT proportion of 84.83 percent. Indonesia PP export to the world amounted to USD 26.328 million, while world supplies to South Korea worth USD 31.036 million, but Indonesia will be supplying to South Korea amounted to USD 1,000. Tariff barriers on AKFTA by 7 percent and Korea also MFN tariff of 7 percent.

- 6-digit HS 441011, in the form of Floor board HS 441011142010. Goods processed wood products have IPT has a proportion of 91.73 percent. Exports of goods from Indonesia into the world market worth USD 30.635 million and South Korea in the supply of the world worth USD 4.572 million while Indonesia supplying to South Korea recently valued at USD 378,000. Sealatan Korea MFN tariff barriers still amounted to 8 percent. Likewise AKFTA rate is still 8 percent.

- 6-digit HS 540233, in the form Of poly trimethyler with HS 5402331000. textile export item featured IPT has a proportion of 82.34 percent. These products are widely supplied to the world worth USD 176.291 million while South Korea supplied the world amounted to USD 211683000 means more demand than ekpsor Indonesia South Korea to the world, while the supply of Indonesia to South Korea are still relatively few, or USD1.995 million. AKFTA turns tariff barriers and Korea still apply MFN tariff rate of 8 percent.

- 6-digit HS 010620, in the form of goods Fresh Water Tortoises HS 010620200. This item is tortoise or freshwater turtle alive. South Korea demand quite a lot and Indonesia to the world supply is quite high while the supply to Korea from Indonesia amounted to 10 percent of South Korea's request. Barriers to entry to South Korea in the form of tariffs by 8 percent and AKFTA also still apply the rate of 8 percent.

- 6-digit HS 030749, in the form of Cuttle Fish HS 0307491010. This item is in the form of cuttlefish or squid either dried or salted. IPTnya fairly large proportion of 83 percent. Exports of goods to the world from Indonesia is very big which is USD 93510 and South Korea demand is also very large, while the supply of Indonesia to Korea is still relatively small. Cuttlefish tariff barriers to entry into South Korea by 10 percent while tariffs are applied AKFTA very high at 27 percent.

- 6-digit HS 390410, in the form of Poly vinyl chloride (PVC) not mixed with any other substances 3904300000 . HS has a PVC Goods IPT proportion of 77.83 percent. These goods are exported to the world worth USD 96.61 million and South Korea imported from the world worth USD 124.125 million while Indonesia supplies to the country of South Korea 0, which means there are still opportunities to enter into South Korea. Tariff barriers for MFN AKFTA 7 percent and Korea also 7 percent.

- 6-digit HS 030624, in the form of goods Blue Crab HS 0306241010. This item is the crab and the like. The proportion of potential indicators tradenya quite large at 65 percent. Export crab Indonesia to the world today is very large, while imports to South Korea in addition to Indonesia (the world) is also quite large, while South Korean imports from Indonesia are very small. It is this which is the potential of this crab stuff can get into South Korea. When viewed from the non-tariff barriers on the forum AKFTA and South Korea MFN tariff is still high at 20 percent.

- 6-digit HS 382311, in the form of acid oil from refining HS 3823192000. This item has IPT proportion of 78 percent. Indonesia to supply goods to the world is very large USD 1.431011 billion. Likewise, South Korea needs for goods is also quite large but the supply Indonesia to South Korea are still relatively few. AKFTA tariff barriers for MFN subject to 8 per cent and South Korea are also 8 percent.

- 6-digit HS 170290, in the form of HS 1702901000. IPT Artificial Honey Honey Artificial proportion is large enough that 54.09 percent of the potential acquisition is also very large which is USD 83.813 million. When viewed Artificial Honey exports to the world amounted to USD 34.743 million, while demand for South Korea and Indonesia worth USD 63.765 million Artificial Honey supplies to South Korea is still relatively small in the amount of USD 252,000. When viewed AKFTA tariff barriers turns exports still amounted to 24 percent, as well as South Korea MFN rate is still high at 24 percent.

- 6-digit HS 291612, in the form of Ethyl Acrylate Chemical Goods HS 2916121000. IPT has a proportion of 50.13 percent. Exports of goods to the world this chemical is relatively large in value and South Korea imports of the world is also very large, 2 -fold Indonesia's exports to the world. But 
South Korean imports from Indonesia is still very little. The problem is that barriers to AKFTA rates of 7 percent and South Korea MFN rates by 7 percent as well.

- 6-digit HS 220290, goods Based on Ginseng Beverage HS 220290100. Goods processed products has the potential to be able to enter more into South Korea. IPTnya proportion of 50.37 percent and South Korea demand is higher than supply Indonesia to the world. Barriers to AKFTA rate was 8 percent while tariff barriers to entry to South Korea is 8 percent as well.

- 6-digit HS 200820, in the form of HS 2008200000. Pineapples Pineapples can potentially get into South Korea. This stuff has a proportion IPT 97.42 percent, Indonesia supplying very large world that is worth USD 165.69 million. South Korea needs or supply the world to South Korea worth USD 16.696 million and supply Indonesia to South Korea are still relatively small in the amount of USD 431,000 . When viewed barrier to entry to South Korea turns AKFTA rates by 30 percent and South Korea MFN tariff is also 30 percent.

- 6-digit HS 390110, in the form of linear low density polyethylene with HS 3901101000. This chemical goods IPT has the proportion of 39.04 percent. This chemical goods entry into the world market of Indonesia valued at USD 87.722 million and imports to South Korea the world market valued at USD 224.496 million but supply Indonesia to South Korea only worth $\$ 71,000$. AKFTA both tariff barriers and Korea MFN rates by 7 percent.

- 6-digit HS 871200 form of racing bicycles with HS 8712001000 . This product has a proportion of 20 percent and Indonesia ITP has supplied to the worldwide market worth USD 41.203 million and the needs of South Korea which has been supplied from the world market valued at USD 207.169 million. whereas the new Indonesia supplying to South Korea worth USD 7,000. Tariff barriers by 8 percent better turns AKFTA and South Korea MFN rates.

- 6-digit HS 080 450, in the form of Guava (Guavas) HS 0804501000. type of fruit has the potential to export to South Korea. Indication of the potential of trade is 18 percent. Indonesia can export to the world Guava enough value amounted to USD 8.45 million and goods coming into South Korea amounted to USD 46.142 million, Indonesia's exports to South Korea only worth USD 1,000. Export restrictions turned out to be a good high tariffs still MFN tariff rates AKFTA and South Korea is at 30 percent.

- 6-digit HS 030 199, in the form of goods Yellow Tail HS 0301992000. Indonesia's export of fish to the world market is quite high and South Korea demand is also high, while Indonesia's exports to Korea is still 0 . This could be due to tariff barriers because South Korea is still imposing tariffs 10 percent and rates AKFTA forum also impose 10 percent.

- 6-digit HS 060314, in the form of chrysanthemum flowers (Chrysanthemums) HS 0603140000. This flower type has the proportion of IPT for export to South Korea 100 percent. Indonesia's exports to the world are relatively high and South Korea demand for these products is greater than the entire Indonesian exports to the world while Indonesia's exports to South Korea still 0 . When viewed tariff barriers to exports of chrysanthemums in the forum AKFTA charged 25 percent and Korean MFN tariffs also 25 percent.

- 6-digit HS 271019 in the form of jet fuel (jet fuel) HS 2710191010. This fuel value is very high, although the proportion of IPT was not too big that only 7.16 percent. For jet fuel, Indonesia could supply the world market amounted to USD 772.863 million and South Korea to the world supply is very large USD 7.760657 billion, while Indonesia to supply Korea's only worth USD 216.939 million, which means they have the potential to enter the South Korean market, When seen his AKFTA rate of 5 percent, as well as MFN South Korea by 5 percent.

- 6-digit HS 130219, in the form of White ginseng extract ginseng extract HS 1302191110. Goods IPT has a proportion of 2.31 percent. These goods demand is very high in South Korea reached \$ 123.799 .00 which has been supplied from the world market. Indonesia only supplies around USD 2,910 to supply the world market while Indonesia to South Korea only USD 45,000. Tariff barriers for entry into South Korea, for AKFTA rates by 20 percent and South Korea MFN tariff of 20 percent.

- 6-digit HS 100590, in the form of Popcorn HS 1005902000. potential export item Indonesia has only IPT proportion of 0.42 percent. But the South Korean demand for goods is so large that a USD 2.629.308 while the value of trade Indonesia to South Korea amounted to only USD 12,000. One obstacle is the high tariff AKFTA and South Korea MFN rates by 63 percent. 


\section{Conclusion and Recommendation}

The results of the IPT analysis showed that some items may be proposed in cooperation IKCEPA forum are prime export goods Indonesia HS 6 digit that have the potential as export goods to South Korea one of which has a high proportion of IPT and South Korea demand is very large. In addition, it can also be established in IKCEPA forum about both tariff barriers and MFN tariff rates AKFTA South Korea. This is one factor that dominates the difficulty of potential Indonesian export goods enter the South Korean market.To increase the value of Indonesia's exports to South Korea, dialogue and bilateral cooperation should be supported especially that benefits both parties related tariffs on South Korean government. Besides, it needs to be discussed and negotiated as well as for the South Korean government to provide access to the market leading products in Indonesia. As seen from the structure of the tariffs applied South Korea, South Korean government has tended to protect the products of the farm. This is a concern also for the Indonesian government to be able to apply the same policy to protect agricultural products.

As the material IKCEPA discussion forum of cooperation, there are several items featured Indonesian exports of HS 6 digit that has the potential to enter the market of South Korea. The export items include chemicals, ores plastics such as PE and PP, fuel oil, liquefied natural gas. Likewise, exports of goods such as textiles, wood and some manufactured goods such as bicycle components, household appliances, ginseng extract, soy sauce. Likewise, live animals such as fish, freshwater turtles, crabs, cuttlefish or squid. Including agricultural products such as ginseng, honey, flowers, fruits such as guava, pineapple and mangosteen are still wide open to be discussed in the forum IKCEPA. In the future, should delegate IKCEPA forum can better focus on discussing featured Indonesian goods to enter Korea.

\section{References}

Boediono. (1981). International Economics, Introduction to Economics, Series First Sinopsis, Edisi. BPFE, Yogyakarta, Indonesia. p. 56.

Christian, H. \& Pasteels, J. M. (2006). Assesing Bilateral Trade Potential at the Commodity Level: An Operational Approach, International Trade Centre, Geneva

De Silva, N. (2012). Trade Liberalization Effects on Agricultural Production Growth: The case of Sri Lanka. Journal of International Agricultural Trade and Development, 8(2), the University of Minnesota Department of Applied Economics.

Grosse, R. (1996). International Technology Transfer in Services (PDF). Journal of International Business Studies, 27, 782.

Helmers, C. (2006). Options for Mongolia for the Formation of Bilateral Free Trade Agreements - Options in Merchandise Trade: An Overview. Mongolian Ministry of Industry and Trade, Trade Analysis and Negotiations Unit (UNDP, GTZ, USAID).

ITC (UNCTAD/WTO). (2006). Assessing Bilateral Trade Potential at the Commodity Level, Market Analysis Section (MAS) International Trade Center Geneva, Switzerland.

ITC. (2001). An Operational Approach: Foreign Trade Statistics: A guide to their use in market research, ITC technical paper 2001, ITC/T307.E/PMD/MAS/01-IX.

Juan, B. (2014). Latin Americas Missing Global Value Chains, source http://www.voxeu.org/article/latinamericas-missing-global-value-chains, downloaded August, 25 at $11.50 \mathrm{pm}$ )

PKRB. (2013). Influence of FTA and EPA on trade and investment flows with the Partner Country, PKRB BKF, Ministry of Finance, Indonesia

The Decade Long Journey of Korea's FTA. (2014). ITT Working Paper No.14-01, Myoung, Jin ho Jung , Hye Sun Je, Hyung Jun Mung, Seol Ji, Seoul -Korea.

Trade Map User Guide. (2014). Trade statistic for international business development, International Trade Centre, Geneva.

Viner, J. (1950). The Customs Union Issue. Carnegie Endowment for International Peace, New York. 


\section{Appendix}

\section{Appendix 1: Thirty-type Potential Export Products Indonesia Negotiated}

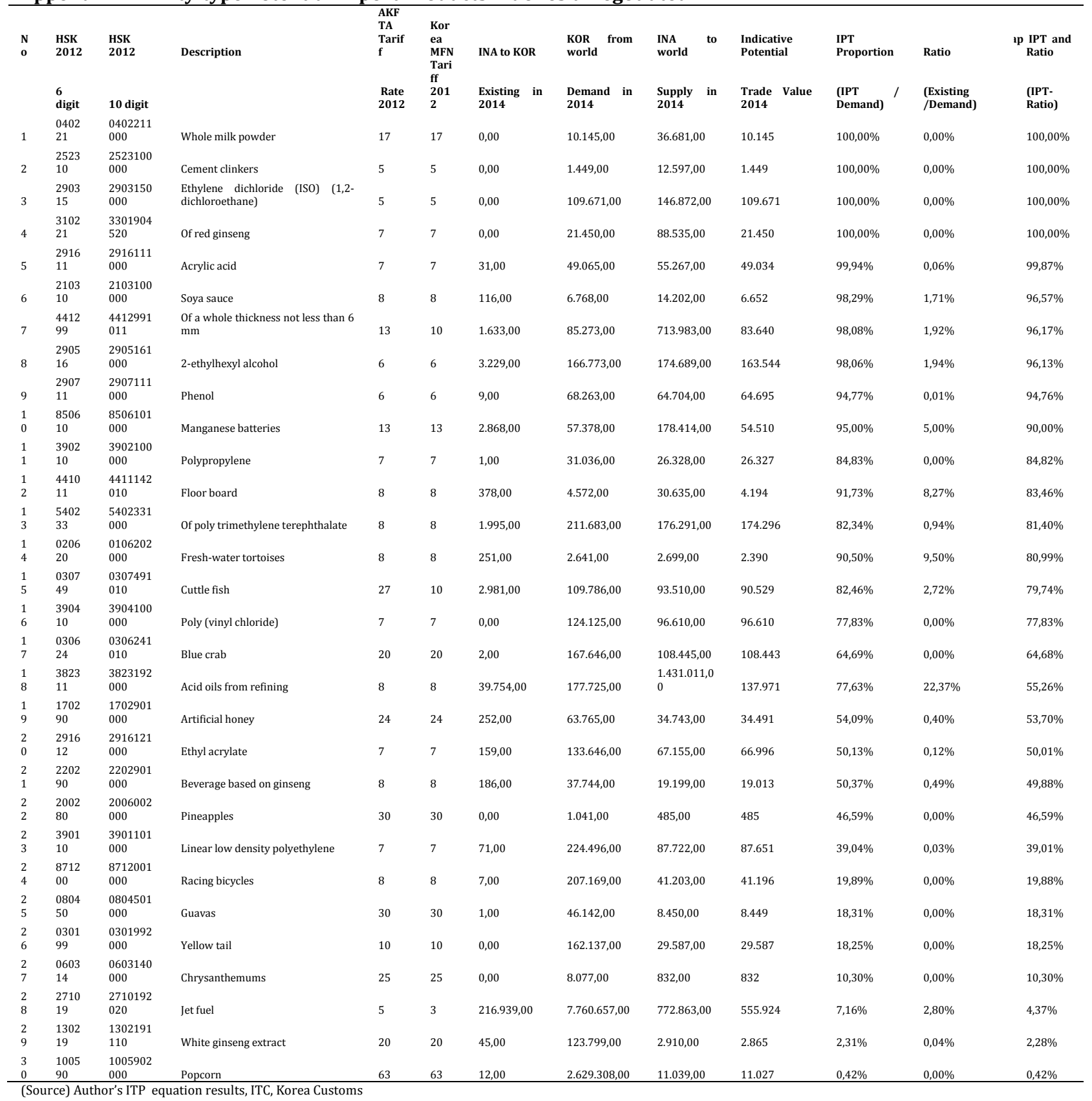

